\title{
Different Generation of Inhibitors against Gallic Acid-Induced Apoptosis Produces Different Sensitivity to Gallic Acid
}

\author{
Kazuto Isuzugawa, Yukio Ogihara, and Makoto Inoue* \\ Department of Pharmacognosy, Faculty of Pharmaceutical Sciences, Nagoya City University, 3-1 Tanabe-dori, Mizuho-ku, \\ Nagoya 467-8603, Japan. Received July 28, 2000; accepted November 13, 2000
}

\begin{abstract}
Gallic acid (3,4,5-trihydroxybenzoic acid), a naturally occurring plant phenol, showed selective cytotoxicity against tumor cells with higher sensitivity than normal cells such as hepatocytes and keratinocytes. To elucidate the difference in sensitivity between normal and tumor cells to gallic acid, we studied whether the inhibitor of gallic acid-induced apoptosis existed or not. A serum-free conditioned medium, prepared from high density rat primary cultured hepatocytes and cytoplasm of hepatocytes, prevented gallic acid-induced apoptosis. In contrast, hepatomas and hepatic cell lines such as dRLh-84, PLC/PRF/5, HLE, and HUH and two other kinds of tumor cell, HeLa and KB, scarcely generated such an inhibitor in either their conditioned medium or their cells. Biochemical characterization of the inhibitors revealed that the inhibitor in the hepatocyte conditioned medium was completely inactivated by heating at $65^{\circ} \mathrm{C}$ for $10 \mathrm{~min}$. Its molecular weight was estimated at $150-250 \mathrm{kDa}$ by gel filtration column chromatography, indicating that the inhibitor may be a protein-like substance. These results suggest that the generation of a large amount of the inhibitor may endow hepatocytes with insensitivity to gallic acid. In conclusion, the difference in the amount of the inhibitors generated by hepatocytes and tumor cells should contribute to the underlying mechanism in the difference in sensitivity of cells to gallic acid.
\end{abstract}

Key words gallic acid; apoptosis; selectivity; inhibitor; tumor cell

Plant-originating anticancer drugs such as camptothecin, taxol, podophyllotoxin, vinblastine and vincristine represent some of the most important drugs currently used clinically for the treatment of human cancers. These compounds have also been used as lead compounds for the development of novel anticancer chemotherapeutic drugs. Their basic studies revealed that they caused apoptosis in tumor cells by unique mechanisms. For example, taxol was found to stabilize tubulin polymerization, cause mitotic arrest, and induce caspase3 activation and bcl-2 phosphorylation, resulting in apoptosis induction. $^{1,2)}$ Camptothecin and podophyllotoxin are topoisomerase I and II inhibitors, respectively, ${ }^{3,4)}$ and vinblastine and vincristine inhibit microtubule assembly. ${ }^{5)}$ Finally, they cause cell death accompanied by cell shrinkage, chromatin condensation, apoptotic body formation, and DNA fragmentation characteristic of apoptosis. ${ }^{6)}$ However, their drawback as anticancer chemotherapeutic drugs is that they show non-specific cytotoxicity at a relatively low concentration. An ideal anticancer drug would have little non-specific cytotoxicity and highly specific cytotoxicity for neoplasma. It was recently reported that some natural products exhibit specific or selective cytotoxicity against some kinds of tumor cells. For example, betulinic acid, which was isolated from the stem bark of white birch trees, was identified as a melanoma-specific cytotoxic agent in cell culture and animal models, ${ }^{7,8}$ and showed less cytotoxicity against other kinds of tumor cells such as hepatoma, lymphoma, colon cancer and so on. Bufalin, one of the components of bufadienolides in the traditional Chinese medicine chan'su prepared from toad venom, has a potent growth inhibitory effect on human cancer cells, but it is less potent on mouse and rat tumor cells. ${ }^{9}{ }^{9}$ In our previous study, gallic acid (3,4,5-trihydroxybenzoic acid), a naturally occurring plant phenol, which has been reported to show a number of biological activities, ${ }^{10-16)}$ was found to induce apoptosis in tumor cells such as HL-60RG, HeLa, dRLh-84, $\mathrm{PLC} / \mathrm{PRF} / 5$, and KB cells with higher sensitivity than normal cells, such as rat primary cultured hepatocytes, keratinocytes, macrophages, endothelial cells and fibroblasts. ${ }^{17,18)}$ In addition, the selectivity shown by gallic acid was independent of the progression of the cell cycle, that is, gallic acid does not act at a specific phase of the cell cycle. The structure-activity relationship study revealed that methylation of the phenolic hydroxyl group, and esterification of the carboxyl group, markedly reduces cytotoxic activity. ${ }^{18,19)}$ From the study to determine the gallic acid-eliciting signaling pathway in various kinds of cell lines, intracellular $\mathrm{Ca}^{2+}$ and reactive oxygen species (ROS) would turn out to be common denominators, although the death signal induced by gallic acid was diverse among different cell lines. ${ }^{20)}$ In the course of the study of gallic acid, we found that gallic acid failed to induce cell death in tumor cells in the co-culture with hepatocytes. This suggests that gallic acid-resistant cells seem likely to generate an inhibitor and protect themselves from the cytotoxicity of gallic acid. In this study, we therefore explored the mechanism by which gallic acid induces apoptosis in tumor cells with higher sensitivity, focusing on the inhibitors of gallic acid-induced cell death.

\section{MATERIALS AND METHODS}

Materials Gallic acid (Nakalai Tesque Co., Kyoto, Japan) was recrystalized from hot water and used for the following experiment. Donor bovine calf serum (BS), fetal calf serum (FCS), MEM-Eagle's salts (with non-essential amino acids), Dulbecco's minimum essential medium (DMEM), and RPMI1640 were obtained from Irvine Scientific Co. (Santa Ana, CA, U.S.A.). Lactalbumin hydrolysate (LAH) and antibiotics (penicillin and streptomycin) were from Life Technologies, Inc. (Grand Island N.Y., U.S.A.). Trypsin (pancreas protease) and trypsin inhibitor were from Merck Co. (Frankfurt, Germany) and Sigma Chemical Co. (St. Louis, MO, U.S.A.).

Cell Culture dRLh-84 (rat hepatoma), HeLa (human ep- 
itheloid carcinoma), PLC/PRF/5 cells (human hepatoma), KB(human epidermoid carcinoma), HLE (human hepatoma, non-differentiated), and HUH-7 (human hepatoma, differentiated) were provided from the Japan Cancer Research Resources Bank. dRLh-84 cells were cultured in MEM-Eagle's salts medium (with non-essential amino acids) supplemented with $20 \% \mathrm{BS}, 50 \mathrm{U} / \mathrm{ml}$ penicillin and $50 \mu \mathrm{g} / \mathrm{ml}$ streptomycin. $\mathrm{PLC} / \mathrm{PRF} / 5$ cells were cultured in RPMI1640 medium supplemented with $10 \% \mathrm{FCS}, 6.5 \mathrm{mg} \mathrm{LAH}, 50 \mathrm{U} / \mathrm{ml}$ penicillin and $50 \mu \mathrm{g} / \mathrm{ml}$ streptomycin. HeLa and KB cells were cultured in MEM-Eagle's salts medium (with non-essential amino acids) supplemented with $10 \% \mathrm{FCS}, 50 \mathrm{U} / \mathrm{ml}$ penicillin and $50 \mu \mathrm{g} / \mathrm{ml}$ streptomycin. HLE and HUH-7 cells were cultured in Dulbecco's MEM medium supplemented with $10 \%$ FCS, $50 \mathrm{U} / \mathrm{ml}$ penicillin and $50 \mu \mathrm{g} / \mathrm{ml}$ streptomycin.

Preparation of the Conditioned Medium of Hepatocytes or dRLh-84 Cells Hepatic parenchymal cells were isolated from male SD rats $(300 \mathrm{~g})$ by the two-step collagenase perfusion method of Seglen. ${ }^{21)}$ Cell viability was determined by the $0.25 \%$ trypan blue dye exclusion method, and cells with viability more than $91.3 \pm 1.0 \%(n=9)$ were used in this study. Hepatocytes were seeded into collagen-coated culture dishes at a density of $5 \times 10^{5}$ cells/well and incubated in William's E medium ( $\mathrm{pH} 7.4$ ), supplemented with $10 \%$ FCS, $100 \mathrm{U} / \mathrm{ml}$ penicillin, $100 \mu \mathrm{g} / \mathrm{ml}$ streptomycin, $10^{-7} \mathrm{M}$ insulin and $10^{-7} \mathrm{M}$ dexamethazone. After incubation for $4 \mathrm{~h}$ at $37{ }^{\circ} \mathrm{C}$ in an atmosphere of $95 \%$ air and $5 \% \mathrm{CO}_{2}$, the hormone-containing medium was removed from the wells. The cells were washed twice with phosphate-buffered saline (PBS) and then incubated in William's E medium without FCS for $24 \mathrm{~h}$. The resulting culture conditioned medium was used in the following study. The culture conditioned medium of dRLh- 84 cells was prepared as follows. After dRLh-84 cells became confluent, the culture medium was changed with fresh medium without serum, followed by incubation in an atmosphere of $95 \%$ air and $5 \% \mathrm{CO}_{2}$ for $24 \mathrm{~h}$. The resulting culture conditioned medium was used in the following study.

Gel Chromatography The hepatocyte conditioned media $(320 \mathrm{ml}$ each) were concentrated to $6 \mathrm{ml}(16.4 \mathrm{mg})$, using Diaflo membrane XM50 (Amicon). The concentrates were applied to Sephacryl S-200 previously equilibrated with Hanks salt solution and 5-ml fractions were collected and monitored at $280 \mathrm{~nm}$. Then, $50 \mu \mathrm{l}$ of each fraction was directly used for the assay of gallic acid-induced cell death inhibitory activity.

Assay of the Inhibitory Activity against Gallic Acid-Induced Cell Death dRLh- $84\left(5 \times 10^{4}\right.$ cells $\left./ \mathrm{ml}\right)$ were seeded into a 96-multi-well plate and cultured for $12 \mathrm{~h}$. The conditioned media, cytosol, or the effluent from Sephacryl S-200 column, were added to the culture $30 \mathrm{~min}$ before the addition of gallic acid $(50 \mu \mathrm{g} / \mathrm{ml})$. Following a $6 \mathrm{~h}$ culture in $5 \% \mathrm{CO}_{2}$ in air, cell viability was determined by measuring the number of surviving cells using the $3^{\prime}$-(4,5-dimethylthiazol-2-yl)-2,5diphenyl-tetrazolium bromide (MTT). ${ }^{22)}$

\section{RESULTS}

We previously reported that gallic acid showed cytotoxicity against all tumor cells tested in the study with higher sensitivity (around $35 \mu \mathrm{M}$ of $\mathrm{IC}_{50} \mathrm{~s}$ ) than normal cells, and that its

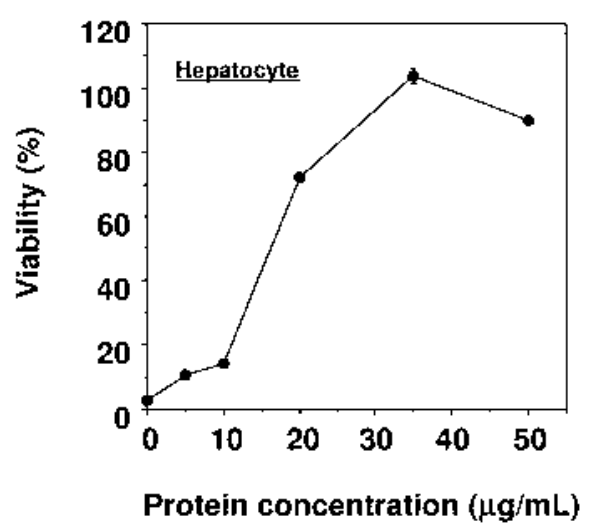

Fig. 1. Effect of Hepatocyte Conditioned Medium on Gallic Acid-Induced dRLh-84 Cell Death

The hepatocyte conditioned medium at the indicated concentration was added to dRLh- 84 cell culture $\left(5 \times 10^{4}\right.$ cells $\left./ \mathrm{ml}\right) 30 \mathrm{~min}$ before the addition of gallic acid at the concentration of $50 \mu \mathrm{g} / \mathrm{ml}$. After $6 \mathrm{~h}$ incubation, cell viability was determined by the MTT method as described in Materials and Methods. Each value represents the mean \pm S.E. of 6 wells.

cytotoxicity was independent of the origin of the tumor cells, i.e. animal species, organ, or tissue. ${ }^{1,18,23)}$ In the present study, to elucidate the underlying mechanism in the selective cytotoxicity shown by gallic acid, we studied whether gallic acid-resistant cells, hepatocytes, generated some kind of inhibitors, and whether gallic acid-sensitive cells, tumor cells, did not. As shown in Fig. 1, the serum-free conditioned medium, which was prepared after $24 \mathrm{~h}$ in a culture of hepatocytes, inhibited gallic acid-induced dRLh-84 cell death dose-dependently, and suppressed cell death completely at the concentration of $50 \mu \mathrm{g}$ of protein $/ \mathrm{ml}$. In contrast, the serum-free conditioned medium, prepared from various hepatoma, such as dRLh-84, HLE, HUH, and PLC/PRF/5 cells, in addition to $\mathrm{KB}$ cells, human epidermoid carcinoma, and HeLa cells, human epitheloid carcinoma, failed to exhibit such inhibitory activity (Fig. 2).

We then determined whether or not such inhibitory activity was detected in cells. Fig. 3 indicated that the cytosol of hepatocytes markedly inhibited gallic acid-induced cell death in a dose-dependent manner, as a hepatocyte conditioned medium. On the other hand, the cytosols of tumor cells used in this study also showed such inhibitory activity, but much less activity than that of hepatocyte cytosol (Fig. 4). Then, to determine what kind of inhibitor was generated by hepatocytes, the inhibitory activities of the hepatocyte conditioned medium was characterized from several viewpoints. When the heat stability was examined, the inhibitory activity in the hepatocyte conditioned medium was completely inactivated following the treatment at $65^{\circ} \mathrm{C}$ for $10 \mathrm{~min}$ (Fig. 5). When $2 \mathrm{ml}$ of the conditioned medium was treated with trypsin $\left(2 \times 10^{4} \mathrm{U}\right)$ at $37^{\circ} \mathrm{C}$ for $3 \mathrm{~h}$, the inhibitory activity in the conditioned medium was not destroyed. When the conditioned media were fractionated by ultrafiltration, almost all of the activity of the hepatocyte conditioned medium was recovered in the fraction greater than $50 \mathrm{kDa}$ (data not shown). We then applied the fraction greater than $50 \mathrm{kDa}$, prepared from hepatocytes, to the gel filtration column of Sephacryl S-200 (Fig. 6 ). The inhibitory activity of hepatocytes was eluted in the fraction from 34 to 46 , indicating that the molecular weight was an estimated $150-250 \mathrm{kDa}$. 

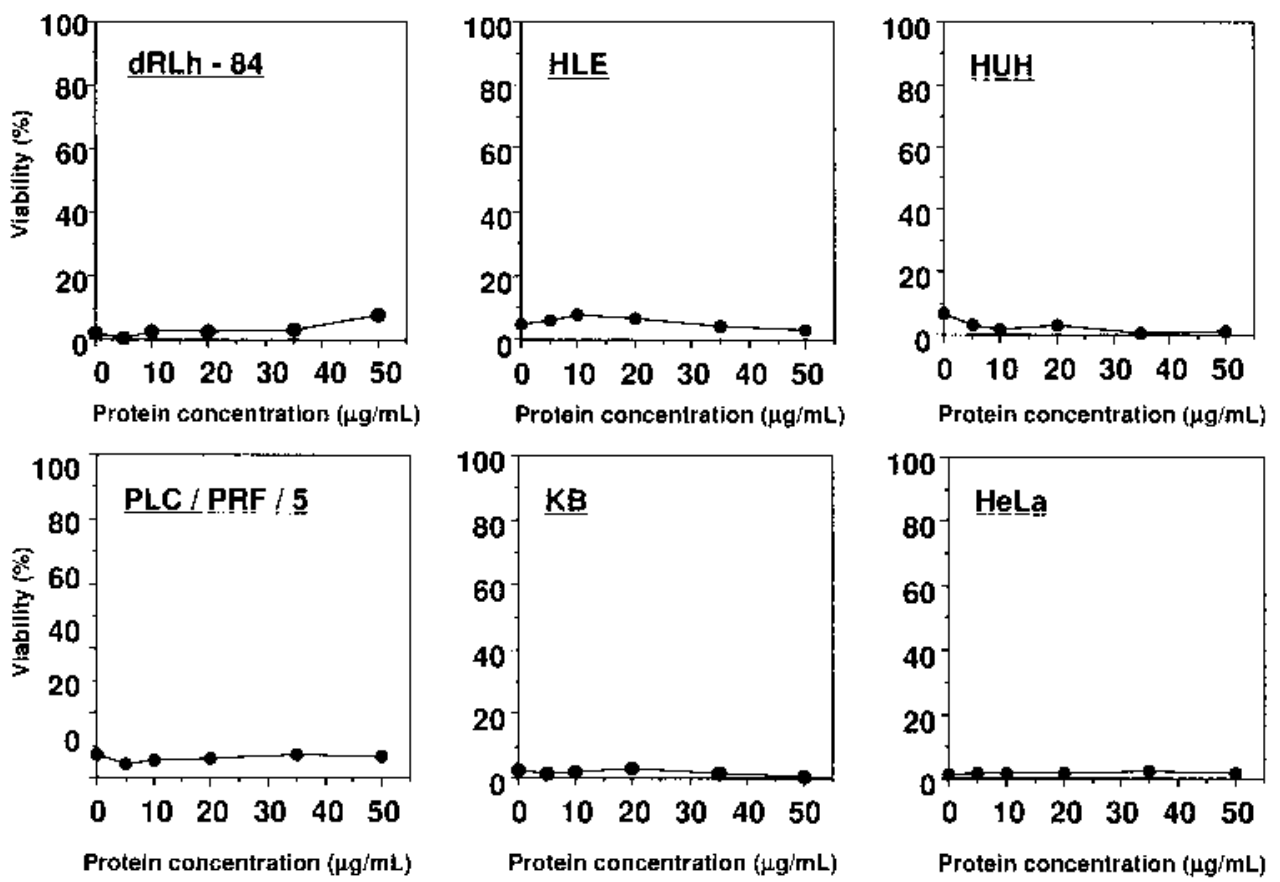

Fig. 2. Effect of the Conditioned Medium of Various Tumor Cells on Gallic Acid-Induced dRLh-84 Cell Death

dRLh-84, HLE, PLC/PRF/5, KB, and HeLa cells conditioned media at the indicated concentration were added to dRLh- 84 cell culture 30 min before the addition of gallic acid at the concentration of $50 \mu \mathrm{g} / \mathrm{ml}$. Cell viability was determined as described in the legend of Fig. 1. Each value represents the mean \pm S.E. of 6 wells.

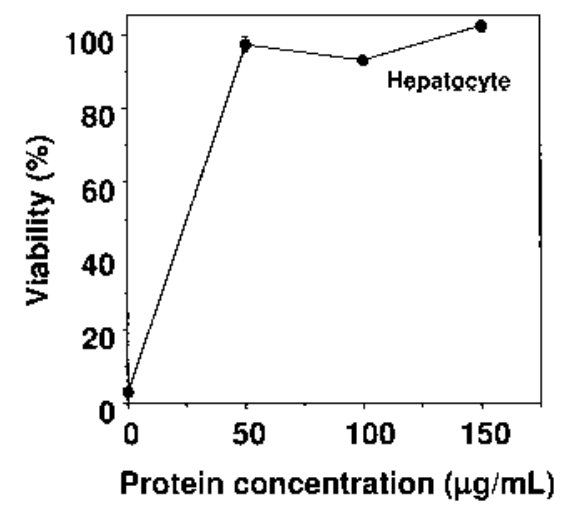

Fig. 3. Effect of the Cytosol of Hepatocytes on Gallic Acid-Induced dRLh-84 Cell Death

The cytosol prepared from hepatocytes was added to dRLh- 84 cell culture at the indicated concentration. Cell viability was determined as described in the legend of Fig. 1. Each value represents the mean \pm S.E. of 6 wells.

\section{DISCUSSION}

Apoptosis is an essential process for maintaining homeostasis in multicellular organisms and is found to play crucial roles in a variety of physiological and pathological conditions. ${ }^{24-26)}$ It is triggered by a variety of physiological and nonphysiological agents that generate a common set of morphological alterations such as cell shrinkage, surface blebbing, chromatin condensation, DNA and nuclear fragmentation, and the formation of apoptotic bodies. ${ }^{27)}$ Cancer is considered to result from extraordinary proliferation of cells, which escape from the surveillance system of damaged or mutated cells. That is, anticancer drugs are expected to modulate the extrinsic and intrinsic regulators of apoptosis and sensitize tumor cells to apoptosis. In addition, selective anticancer drugs, without the cytotoxic effects on normal cells associated with conventional cancer chemotherapy, are required as an ideal anticancer drug. For this purpose, we should find a novel molecular target that is cancer specific or that has a specific machinery of apoptosis induction in tumor cells.

In the present study, we have confirmed that the cytotoxic effect of gallic acid, which induces apoptosis selectively in tumor cells, was dependent on the generation of an inhibitor by cells. Primary cultured hepatocytes were found to generate a large quantity of inhibitor and secrete it into a culture medium. Characterization of the inhibitor indicated that the inhibitor may be a protein-like substance, because it was heat-sensitive, and a secretory substance with its molecular size of $150-250 \mathrm{kDa}$. However, when the conditioned medium was treated with trypsin, the inhibitory activity did not disappear. Although this result suggest that the inhibitor may not be a protein, a possibility remained that a trypsin inhibitor was produced in hepatocyte and secreted in a culture medium. Therefore, we should purify the inhibitor and determine its structure. On the other hand, all the tumor cells tested in the present study generated only a small amount of the inhibitor, which was scarcely found in the culture medium. These results suggested that the difference in the amount of the inhibitors between normal cells and tumor cells should contribute to the selective cytotoxic effect of gallic acid against tumor cells.

We have so far demonstrated that gallic acid induced apoptosis in tumor cells by generating intracellular ROS and $\mathrm{Ca}^{2+}$ as common denominators. ${ }^{20)}$ Physiological concentrations of camptothecin, vinblastine, inostamycin, and adriamycin were then found to generate hydrogen peroxide $\left(\mathrm{H}_{2} \mathrm{O}_{2}\right)$ as a common event in the process of apoptosis. This suggests that the generation of $\mathrm{H}_{2} \mathrm{O}_{2}$ is involved in apoptosis, induced by various anticancer drugs, irrespective of their mode of action. ${ }^{28)}$ In addition, anticancer drug-induced $\mathrm{H}_{2} \mathrm{O}_{2}$ generation is a 

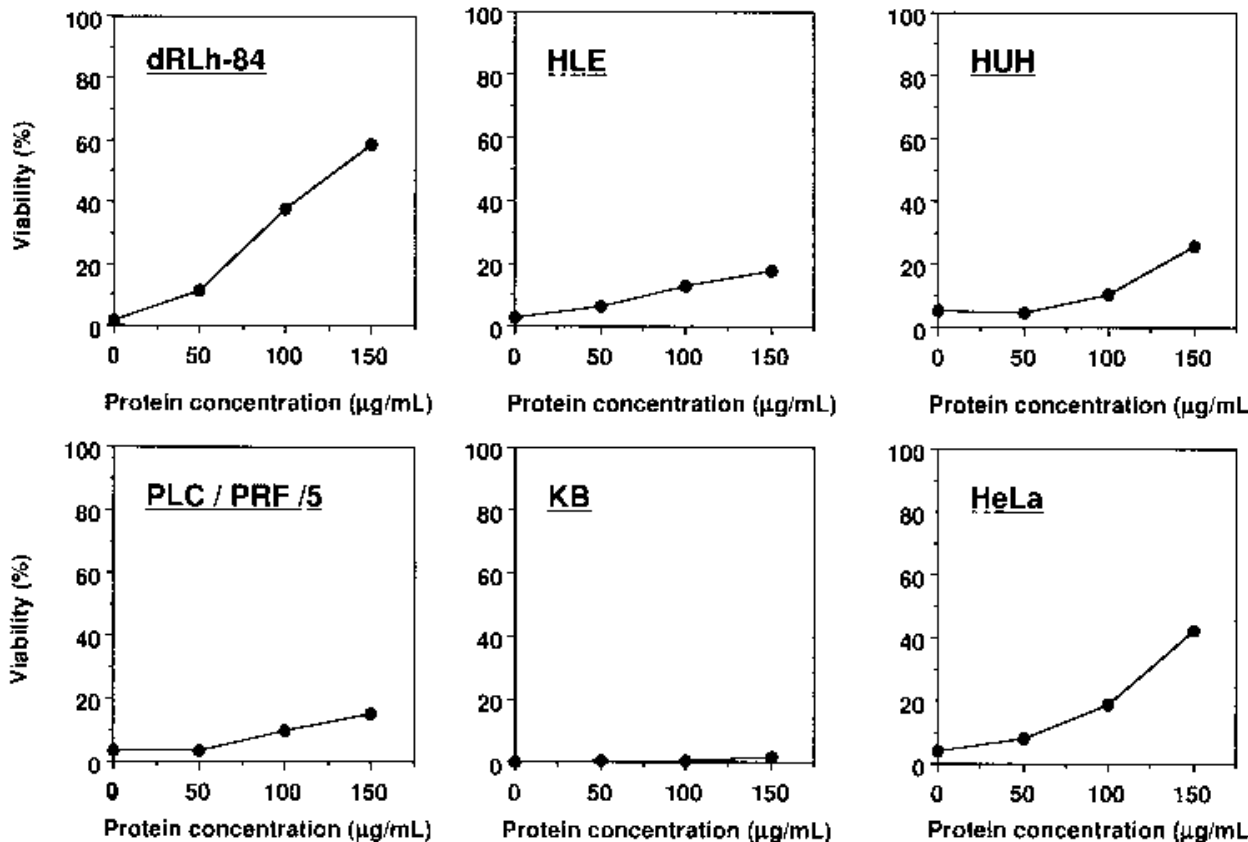

Protein concentration $(\mu \mathrm{g} / \mathrm{mL})$

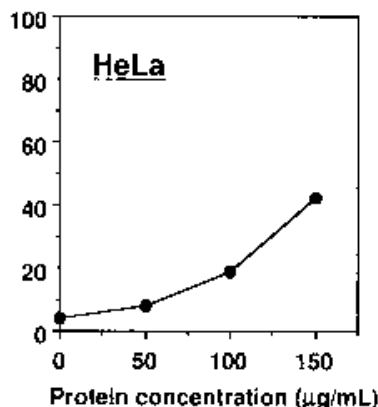

Fig. 4. Effect of the Cytosols of Various Tumor Cells on Gallic Acid-Induced Cell Death

The cytosols prepared from dRLh-84, HLE, HUH, PLC/PRF/5, KB, and HeLa cells was added to dRLh-84 cell culture at the indicated concentration. Cell viability was determined as described in the legend of Fig. 1. Each value represents the mean \pm S.E. of 6 wells.

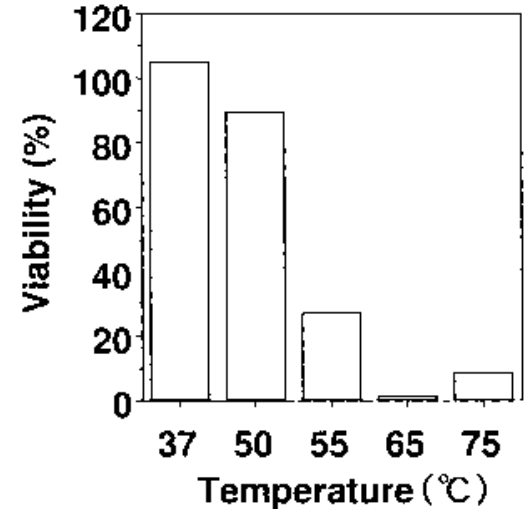

Fig. 5. Heat Stability of Inhibitory Activity against Gallic Acid-Induced Cell Death in Hepatocyte Conditioned Medium

The hepatocyte conditioned medium was treated at the indicated temperature for 10 min and added to dRLh- 84 cell culture. Cell viability was determined as described in the legend of Fig. 1.

consequence of the activation of caspase- 3 proteases and is detoxified by the overexpression of catalase in tumor cells. ${ }^{29,30)}$ On the other hand, the intracellular $\mathrm{Ca}^{2+}$ rise is involved in apoptosis induction through various signaling pathways. $^{31,32)}$ One proposed pathway is as follows: $\mathrm{Ca}^{2+}$ activates $\mathrm{Ca}^{2+} /$ calmodulin-dependent protein serine/threonine phosphatase calcineurin, which dephosphorylates BAD, a regulator of the mitochondrial permeability transition pore, resulting in the opening of the pore, followed by the release of cytochrome c, activation of caspases, and apoptosis induction. $^{33)}$ Recently, caspase-12 was reported to be activated by intracellular $\mathrm{Ca}^{2+}$ elevation and involved in the endoplasmic reticulum-specific apoptosis pathway. ${ }^{34)}$ In addition, direct activation of the $\mathrm{Ca}^{2+}$ dependent neutral protease, calpain, and nuclear scaffold protease, appears to represent another target for $\mathrm{Ca}^{2+}$ action in apoptosis. ${ }^{35,36)}$ According to a recent report, some diphenols and triphenols, such as gallic acid and

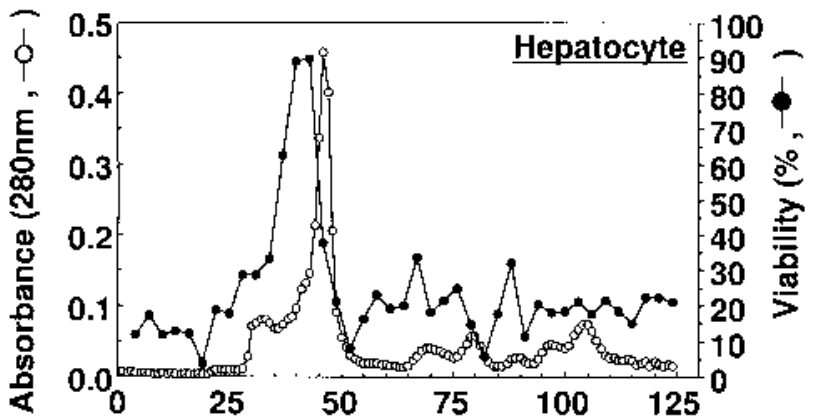

Fraction number (5mL/ tube)

Fig. 6. Gel Filtration with Sephacryl S-200 of Hepatocyte Conditioned Medium

The hepatocyte conditioned medium fractionated by ultrafiltration at the molecular size of $50 \mathrm{kDa}$ was concentrated and applied to Sephacryl S-200. Each $5 \mathrm{ml}$ elution was collected and used for the inhibitory activity against gallic acid-induced cell death. Open and closed circles represent the absorbance of protein at $280 \mathrm{~nm}$ and cell viability was determined as described in the legend of Fig. 1, respectively.

its ester, serve as excellent inhibitors of partially purified human spleen protein tyrosine kinase. ${ }^{37)}$ As a characteristics of tumor cells, the expression of tyrosine kinase, coded in oncogenes, is enhanced in many tumor cells, which is intimately linked to abnormal proliferation of tumor cells. A recent finding indicated that various kinase, including $\left.\mathrm{Akt},{ }^{38}\right)$ PKA, ${ }^{39)} \mathrm{p} 90^{\mathrm{RSK}}{ }^{40)}$ and $\mathrm{p} 21^{\mathrm{PAK} 1},{ }^{41)}$ are able to phosphorylate $\mathrm{BAD}$, resulting in the inhibition of apoptosis and the stimulation of proliferation. Considering what kind of inhibitor against gallic acid-induced cell death is generated in normal cells, the first candidate would be a ROS scavenging enzyme. The antioxidant system of hepatocellular carcinoma cells is known to be severely impaired. ${ }^{42,43)}$ Superoxide dismutase (SOD), catalase, and glutathione peroxidase (GPX), are three major anti-oxidant enzymes and appear to be the most important in mammalian cells. Among them, catalase is re- 
markably reduced in hepatoma tissue when compared with the amount in normal liver tissue. ${ }^{44)}$ SOD, especially MnSOD, has been found to be significantly low in different types of cancer. ${ }^{45}$ GPX activity is variable, depending on the type of tumor. ${ }^{46)}$ These enzymes exist in several forms and are highly compartmentalized in the cell. Catalase is found in cytosol and peroxisome, ${ }^{47}$ MnSOD is primarily in the mitochondria, ${ }^{48)}$ and GPX is detected in cytosol and mitochondria, ${ }^{49)}$ suggesting that these enzymes are not likely to be released from hepatocytes or tumor cells. In this respect, the inhibitors that we found seem unlikely to be the ROS scavenging enzymes. However, as there may be a specific machinery to secrete intracellular catalase, we are presently working to clarify the underlying mechanism in catalase secretion.

Furthermore, although $\mathrm{Ca}^{2+}$ signaling and protein phosphorylation, which are considered to be involved in gallic acid-induced signaling pathway to apoptosis, may be the targets of the inhibitor that we found in the present study, we have not yet obtained evidence that explains the inhibitory activity. In conclusion, gallic acid-induced apoptosis showed that tumor cells are sensitive to gallic acid, whereas normal cells, such as primary cultured hepatocytes, show resistance to it. The underlying mechanism in this selectivity shown by gallic acid would result from the generation of the inhibitor against gallic acid-induced apoptosis by normal cells. On the other hand, most tumor cells were able to generate only a small amount of the inhibitor, regardless of the species of cell lines. We then propose the idea in the present study that normal cells have a specific machinery to protect themselves from apoptosis, but tumor cells do not, suggesting that utilization of such a protection system should lead to the development of novel cancer-specific anticancer drugs. Presently, we are enthusiastically working to determine the structure of the inhibitors.

Aknowledgments This study was supported by a Grantin-Aid for Scientific Research (B) from the Ministry of Education, Science, Sports and Culture, Japan.

\section{REFFERENCES}

1) Schiff P. B., Fant J., Horwitz S. B., Nature (London), 277, 665-667 (1979).

2) Haldar S., Chintapalli J., Croce C. M., Cancer Res., 56, 1253-1255 (1996).

3) Kaufmann S. H., Cancer Res., 49, 5870-5878 (1989).

4) Walker P. R., Smith C., Youdale T., Leblance J., Whitfield J. F., Sikorska M., Cancer Res., 51, 1078-1085 (1991).

5) Harmon B. V., Takano Y. S., Winterford C. M., Potten C. S., Cell Proli., 25, 523-536 (1992).

6) Wyllie A. H., Anticancer Res., 5, 131-136 (1985).

7) Pisha E., Chai H., Lee I. S., Chagwedera T. E., Farnsworth N. R., Cordell G. A., Beecher C. W. W., Fong H. H. S., Kinghorn A. D., Brown D. M., Wani M. C., Wall M. E., Hieken T. J., Das Gupta T. K., Pezzuto J. M., Nature Med., 1, 1046-1051 (1995).

8) Schmidt M. L., Kuzmanoff K. L., Ling-Indeck L., Pezzuto J. M., Eur. J. Cancer, 33, 2007-2010 (1997).

9) Jing Y., Ohizumi H., Kawazoe N., Hashimoto S., Masuda Y., Nakajo S., Yoshida T., Kuroiwa Y., Nakaya K., Jpn. J. Cancer Res., 85, 645651 (1994).

10) Hamada S., Kataoka T., Woo J. T., Yamada A., Yoshida T., Nishimura T., Otake N., Nagai K., Biol. Pharm. Bull., 20, 1017-1019 (1997).

11) Grichner T., Pospisil F., Veleminsky V., Volkeova V., Volke J., Folia Microbiol., 32, 55-62 (1987).
12) Huang M. T., Chang R. L., Wood A. W., Newmark H. L., Sayer J. M., Yagi H., Jerina D. M., Conney A. H., Carcinogenesis, 6, 237-242 (1985).

13) Mirvish S. S., Cardesa A., Wallcave L., Shubik P., J. Natl. Cancer Inst., 55, 633-636 (1975).

14) Gali H. U., Perchellet E. M., Perdhellet J. P., Cancer Res., 51, 28202825 (1991).

15) Parker W. B., Nishizawa M., Fisher M. H., Ye N., Lee K. H., Cheng Y. C., Biochem. Pharmacol., 38, 3759-3765 (1989).

16) Elford H. L., Wampler G. L., van't Riet B., Cancer Res., 39, 844-851 (1979)

17) Inoue M., Suzuki R., Koide T., Sakaguchi N., Ogihara Y., Yabu Y., Biochem. Biophys. Res. Commun., 204, 898-904 (1994).

18) Inoue M., Suzuki R., Sakaguchi N., Li Z., Takeda T., Ogihara Y., Jiang B., Chen Y., Biol. Pharm. Bull., 18, 1526-1530 (1995).

19) Li Z., Inoue M., Nose M., Kojima K., Sakaguchi N., Isuzugawa K., Takeda T., Ogihara Y., Biol. Pharm. Bull., 22, 326-329 (1999).

20) Sakaguchi N., Inoue M., Ogihara Y., Biochem. Pharmacol., 55, 1973-1981 (1998).

21) Seglen P. O., Exp.Cell Res., 74, 450-454 (1972).

22) Mosman T., J. Immunol. Methods, 65, 55-63 (1983).

23) Sakaguchi N., Inoue M., Isuzugawa K., Ogihara Y., Hosaka K., Biol. Pharm. Bull., 22, 471-475 (1999).

24) Furtwangler J. A., Hall S. J., Koskinen M. L., Acta Anat., 124, 74-80 (1985).

25) Schulte-Hermann R., Timmermann-Trosiener I., Barthel G., Bursch W., Cancer Res., 50, 5127-5135 (1990).

26) Smith C. A., Williams G. T., Kingston R., Jenkinson E. J., Owen J. T. Nature (London), 337, 181-184 (1989).

27) Kerr J. F., Wyllie A. H., Currie A. R., Br. J. Cancer, 26, 239-257 (1972).

28) Simizu S., Takada M., Umezawa K., Imoto M., J. Biol. Chem., 273, 26900-26907 (1998).

29) Speranza M. J., Bagley A. C., Lynch R. E., J. Biol. Chem., 268, 19039-19043 (1993).

30) Bai J., Rodringuez A. M., Melendez J. A., Cederbaum A. I., J. Biol. Chem., 274, 26217-26227 (1999).

31) McConkey D. J., Nicotera P., Hartzell P., Bellomo G., Wyllie A. H., Orrenius S., Arch. Biochem. Biophys., 269, 365-370 (1989).

32) Tsubata T., Wu J., Honjo T., Nature (London), 364, 645-648 (1993).

33) Wang H. G., Pathan N., Ethell I. M., Krajewski S., Vamaguchi Y., Shibasaki F., McKeon F., Bobo T., Franke T. F., Reed J. C., Science, 284, 339-343 (1999).

34) Nakagawa T., Zhu H., Morishima N., Li E., Xu J., Yankner B. A., Yuan J., Nature (London), 403, 98-103 (2000).

35) Squier M. K. T., Miller A. C. K., Malkinson A. M. , Cohen J. J., J. Cell Physiol., 159, 229-237 (1994).

36) Clawson G. A., Norbeck L. L., Hatem C. L., Rhodes C., Amiri P., McKerrow J. H., Patierno S. R., Fiskum G., Cell Growth \& Diff., 3, 827-838 (1992).

37) Lazaro I., Palacios C., Gonzalez M., Gonzalez-Porque P., Anal. Biochem., 225, 180-183 (1993).

38) Datta S. R., Dudek H., Tao X., Masters S., Fu H., Goth Y., Breenberg M. E., Cell, 91, 231-241 (1997).

39) Harada H., Becknell B., Wilm M., Mann M., Huang L. J., Taylor S. S., Scott J. D., Mol. Cell Biol., 3, 413-422 (1999).

40) Bonni A., Brunet A., West A. E., Datta S. R., Takasu M. A., Greenberg M. E., Science, 286, 1358-1362 (1999).

41) Schurmann A., Mooney A. F., Sanders L. C., Sells M. A., Wang H. G., Reed J. C., Bokoch G. M., Mol. Cell Biol., 20, 453-461 (2000).

42) Ohuma T., Maldia G., Holland J. F., Cancer Res., 26, 1806-1818 (1966); Datta S. R., Dudek H., Tao X., Masters S., Fu H., Goth Y., Greenberg M. E., Cell, 91, 231-241 (1997).

43) Peskin A. V., Koen Y. M., Zbazsky I. B., FEBS Lett., 1, 41-45 (1978).

44) Corrocher R., Casaril M., Bellisola G., Gabrielli G. B., Nicoli N., Guid G. C., De Sandre G., Cancer, 58, 1658-1662 (1986).

45) Oberley L. W., Buettner G. R., Cancer Res., 39, 1141-1149 (1979).

46) Oberley L. W., Oberley T. D., Mol. Cell Biochem., 84, 147-153 (1988).

47) Holmes R. S., Masters C. J., Arch. Biochem. Biophys., 148, 217-223 (1972).

48) Fridovich I., Advanc. Enzymol., 45, 35-97 (1974).

49) Asayama K., Yokota S., Dobashi K., Hayashibe H., Kawaoi A., Nakazawa S., Histochemistry, 102, 213-219 (1994). 